\title{
Political Risk in Emerging Markets: The Case of AfricaJUICE and Maranque Plants in Ethiopia
}

\author{
Kaleb Demerew \\ University of South Florida
}

\begin{abstract}
This comparative case study examines the experiences of two Dutch horticulture ventures in Ethiopia, East Africa. The first, africaJUICE, specialized in tropical fruit exports, while the second, Maranque Plants, specialized in floriculture exports. The two companies professed a commitment to business ethics and corporate social responsibility, and both operated farms in close proximity to each other in the same region in Ethiopia. This region faced political and social unrest in 2016. However, while africaJUICE's property was torched by rioters, local community elders and stakeholders rushed to protect Maranque Plants' properties from any attacks. This case study examines the political and economic contexts underlying international business ventures, and illuminates the specific business decisions that may have led to diverging outcomes during the Ethiopian political crisis of 2016. As such, it bears particular relevance to issues of business ethics, corporate social responsibility, and political risk in emerging market investments.
\end{abstract}

Keywords: political risk, corporate social responsibility, business ethics, emerging markets, horticulture

\section{INTRODUCTION}

Horticulture is a rapidly growing, vibrant source of hard currency for emerging markets, particularly in East Africa. This comparative case study examines two international ventures, one involved in tropical fruit exports, and one in floriculture exports. The history of international investments in tropical fruit exports is particularly controversial, mostly due to the exploitative practices of multinational companies. For instance, United Fruit's aggressive land-grabs in Central America in the 1930's, and its subsequent ability to veto national governments and dictate policy, gave rise to the term 'banana republic' (Livingstone, 2013). Yet, almost $99 \%$ of tropical fruit production emerges in developing countries or emerging markets (FAO, 2020). Although most of the production is locally consumed, the volume of global trade for tropical fruits was estimated at $\$ 4.5$ billion in 2008 (FAO, 2009). By 2018, exports of tropical fruits had grown to $\$ 13.2$ billion, with Mexico, Costa Rica, and the Philippines as the largest exporters (OEC, 2018). Thus, while tropical fruit trade has grown steadily over the past decade, the major supply chains in Asia and Latin America were affected severely by the Global Financial Crisis (GFC) in 2007-2008, prompting investors to explore alternative supply chains in Africa.

Unlike the case of the tropical fruit industry, the globalization of the floriculture industry was a much later phenomenon, and was mostly driven by constraints on Europe's domestic supply. European demand for flower imports grew after the 1970's, when the energy crisis introduced severe cost constraints to greenhouse floriculture (Button, 2020). With its ideal climate, much of East Africa, particularly, Kenya, Uganda, and Tanzania, gradually emerged as a viable supply chain for these imports (Button, 2020). The 
flower industry netted \$10.7 billion in 2013, with Kenyan exports generating \$34.8 million (GRO Intel, 2015). In Kenya, floriculture investments could expect up to a $63 \%$ margin, with a cost of $\$ 0.11$ per stem and wholesale prices of up to $\$ 0.30$ per stem (GRO Intel, 2015). Ethiopia was a late entrant to this industry, but quickly rose in importance, with over 3,200 fertile hectares available for long-stemmed cut roses alone (Button, 2020). In 2019, the Netherlands comprised almost half of all global flower exports with $\$ 4.6$ billion, while Kenya and Ethiopia, exported \$709.4 million and \$241.3 million, respectively (Workman, 2020).

This comparative case study examines the experiences of two Dutch horticulture firms that sought to operate supply chains in Ethiopia, East Africa. The first, africaJUICE, specialized in sourcing and exporting tropical fruits, while the second, Maranque plants, specialized in floriculture exports. While both companies tried to incorporate Corporate Social Responsibility (CSR) strategies into their ventures, community stakeholders only rushed to protect Maranque's properties during widespread political riots in 2016.

\section{CASE DESCRIPTION}

Following the tropical fruit juice supply crisis in Asia and Latin America in 2009, a Dutch-based agrobusiness, africaJUICE set out to create a supply chain in East Africa. From the beginning, the company branded itself as a socially hyper-conscious enterprise, integrating Corporate Social Responsibility (CSR) initiatives into its mission statement, and building partnerships with local stakeholders. The company's website claims that "africaJUICE strives to be the benchmark for how foreign direct investment is delivered in developing countries" (africaJUICE). The website also highlights the company's belief that integrating environmental protection and poverty eradication should be the "(business) model of choice" (africaJUICE). As an example, it highlights its commitment to low carbon emissions and preference for organic production.

In 2009, africaJUICE launched a joint venture with the Ethiopian government to take control of Tibila Farms, a plot of fertile land in Ethiopia's Oromia region (Ethiopian Investment Commission, 2009). The company started growing different strains of tropical fruits and built a high-tech processing and sterilization facility for its juice production. The processed juice would then be exported back to Europe through the port in neighboring Djibouti. At its peak, africaJUICE employed 2,400 people in Ethiopia (Ethiopian Investment Commission, 2009). The company implemented also initiated a social engagement plan, which included building a free health clinic for its local staff (Secorun, 2016).

In 2016, africaJUICE's production facilities were completely destroyed during massive antigovernment riots by members of Ethiopia's Oromo ethnic group, resulting in tens of millions of dollars' worth of losses. Once a colorful display of rows of tropical vegetation, the company's facilities resembled a "set of a dystopian film" after the protests, with rows of brand-new tractors charred by fire, and computers smashed to pieces (Secorun, 2016). The company's director, Ian Derry, expressed his shock after the attack, saying "no one could have seen this coming" (Secorun, 2016). As far as africaJUICE was concerned, the company was built on a firm foundation of social engagement, sustainability, and support for local communities.

However, most analysts could have easily foreseen the boiling over of political tensions. After the protests, one prominent analyst suggested that foreign investors working with the government were often seen as legitimizers for government repression, while another argued that protestors targeted foreign companies that were seen as being complicit in stealing lands from Oromo farmers (Aglionby and Honan, 2016). In this case, the Ethiopian government had a 10\% stake in africaJUICE (Secorun, 2016).

One of the most contentious issues in Ethiopian politics is land ownership. BTI's country analysis identified critical political events such as "relocation of 70,000 peasants in the Gambela region (to make way for the lease of large tracts of land to foreign investors)" (BTI, 2016, p. 12). Ethiopia's government has also been accused for decades of forcing rural farmers to sell their land and relocate to 'villages' enmasse, under the guise of giving them better access to services (Secorun, 2016). The protests began "over plans to expand Addis Ababa [the federal capital] into Oromo lands" (Aglionby and Honan, 2016). The Ethiopian government allows private land lease, but the government still officially owns all land in Ethiopia. 
Before the 2016 protests, Ethiopia's economic outlook seemed promising, thanks to heavy investment in state infrastructure. Ethiopia had invested heavily in industrialization, attracting large amounts of foreign direct investment into the country. The Economist Intelligence Unit's (EIU) country risk summary shows that Ethiopia maintained a 'stable' currency risk rating from 2009 to 2013, and a 'stable' sovereign risk rating from 2012 to 2013 (EIU, 2009; EIU, 2012; EIU, 2013). While Ethiopia still represented a significant risk to foreign investors, it offered far brighter prospects than its contemporaries in the region did, and continued to attract investment. Dutch companies alone came to employ as many as 70,000 people in Ethiopia (Secorun, 2016). Meanwhile, Ethiopia's emerging market potential was eventually hampered by critical political events, and the 2016 protests were likely the first signs of a major fallout against government-affiliated stakeholders. A year after the riots that resulted in the destruction of africaJUICE investments in Ethiopia, political risk consultancy Stratfor assessed that "revolts in the country have damaged Ethiopia's reputation as a stable destination for investment, causing trade to decline" (Stratfor, 2016).

Ethiopia was seen as the stepping-stone for africaJUICE's expansion into the rest of Africa, but the political realities on the ground caught up with the country's economic forecasts. africaJUICE's factory closed down after the 2016 protests, but the company needed to make some hard decisions about how to move forward. First, it could opt to double down on the Ethiopian supply chain, and reassert its image as a community partner. However, this strategy could backfire in the long run if it was perceived by the public as continued coalescence with the repressive Ethiopian government. Second, africaJUICE could acknowledge the legitimacy of the protests, and draw some distance between itself and the government. It could perhaps try to buy back the shares owned by the government, and engage directly with protest leaders to understand their grievances. But, this strategy could risk disgruntling the Ethiopian government, which could opt to revoke its land lease to the company, or create obstacles to thwart the company's expansion goals. Third, africaJUICE could cut its losses in Ethiopia, and relocate its main supply chain to nearby Tanzania or Kenya, neighboring countries with similar climate and more stable political outlooks. Such a move would cost tens of millions of dollars however, and could put africaJUICE at a competitive disadvantage given the economic opportunity that Ethiopia seems to offer. At any rate, the CEO of Rensen, another Dutch multinational company that was targeted in the protests, seemed to downplay the political risk in Ethiopia, saying that it was "purely bad luck" that foreign companies got caught in the country's political crossfires (Secorun, 2016). Yet, there were indications that the targeting of foreign companies during the 2016 Oromo protests was not random.

Meanwhile, a Dutch-owned flower farm located in the same area as africaJUICE, Maranque Plants, was left untouched by rioters, and was the only commercial operation left standing in the aftermath of the riots (Schemm, 2016). Maranque had invested in community infrastructure, installing water pumps, generators, and flooring in local facilities. Although rioters initially approached the farm, community elders rushed in motorbikes to intervene, warning the rioters that Maranque was their community's property, and that the community relied on the farm (Schemm, 2016). Marc Driessen served as the head of Maranque Plants and recalls feeling alarmed when hundreds of rioters descended on the farm. Asked why he thinks his company's operation was spared while several nearby investments were torched, Driessen says that the answer is simple:

Maranque Plants PLC was very special. We conducted CSR projects within the surroundings of every farm we participated in. The main thing is that as companies investing in Africa, we were very serious about letting the country benefit, especially the local communities around the farm. We developed strong ties with them, because it's better to have a good neighbour than a far friend. The locals who were employed in our farms had a reliable source of income, at least one meal a day, and access to health care. We invested in the local school, we built water wells, and we conducted trainings for the farmers on PPE. We also created opportunities for some of the less skilled workers, assigning them to duties like door attendance and cleaning. Most of all, what we provided 
to the local people and the less fortunate was hope for the future. The farm was there for them. (Driessen, 2020)

\section{CASE QUESTIONS}

1) Imagine that you were appointed regional director of africaJUICE in the aftermath of the 2016 Ethiopian political crisis. What steps would you take to rebuild the company's regional supply chain? Do you believe, as the Renson CEO stated, that rioters targeted specific foreign ventures in Oromia purely out of 'bad luck'? What communication strategies would you implement? Moving forward, how would you integrate considerations of political risk in your CSR strategies in Ethiopia and the broader East Africa region?

2) In what ways did Maranque Plants and africaJUICE plan, communicate, and implement their strategies for Corporate Social Responsibility (CSR)? What were the main differences and similarities between their models? Which model would you implement if you were tasked with managing a new horticulture investment venture in an emerging market in Africa?

3) Why do you think Maranque Plants escaped damage from rioters during the 2016 Ethiopian political crisis? Why did community stakeholders fail to protect other properties, such as those of africaJUICE? How can political risk in emerging markets inform the ways in which companies implement their stated commitments to CSR?

\section{TEACHING NOTES: POLITICAL RISK, CORPORATE SOCIAL RESPONSIBILITY, AND BUSINESS ETHICS}

This comparative case study illuminates increasingly relevant concerns about business ethics and corporate social responsibility in emerging markets investments. As mentioned in the introduction, the history of horticulture investments by multinational companies (MNCs) is especially controversial, having given rise to the phrase 'banana republics'. Often times, MNCs have treated developing countries like "export-processing zones", dumping toxic wastes and third-rate products with little concern for issues of equity in host communities (Ger, 1997). In recent times, international business ventures are increasingly employing ethical analysis and accommodating corporate social responsibility (CSR) concerns for local host communities (Kline, 2010). These CSR concerns should necessarily account for the broader political, societal, and cultural implications of business operations and ventures. Thus, CSR and issues of political risk are inherently linked, even if most multinational ventures tend to consider these issues separately.

In this comparative case study, it is clear that both africaJUICE and Maranque plants intended to consider issues of CSR and business ethics as they launched innovative horticulture supply chains in Ethiopia, East Africa. However, the model of CSR implementation was markedly different in each case. africaJUICE saw its venture as an apolitical project, and failed to account for political risk in implementing its CSR programs. Specifically, it saw no discrepancy between its stated CSR strategies, and its close links with a government that was very unpopular in the Oromia region. By contrast, Maranque Plants limited its ties to the government, as implied in Driessen's statement that a 'good neighbour is better than a far friend'. Instead, the company created a direct communication channel with host community stakeholders. These same stakeholders repaid Maranque's investments in CSR by providing protection amidst civil unrest, leaving Maranque's property undamaged as scores of nearby business establishments were torched. It is clear that Maranque strategically assessed the political risk of investing in Ethiopia and tied this to its implementation of CSR. This is an important aspect of CSR that directly impacts a company's bottom line, yet most MNCs restrict CSR considerations to normative questions of human rights and ethics. While these are very important, this comparative case study shows that CSR, beyond serving as a means to preserve corporate reputation, can actually play a strategic role in guiding investments in emerging markets.

This case may be employed in a variety of international business and leadership courses, particularly in modules related to business ethics, corporate social responsibility, or political risk. Relevant courses include, but are not limited to, Critical Thinking, International Business, International Management, 
Business Ethics, Cultural Management, and Leadership Strategy. The case is designed to stimulate critical thinking about what CSR constitutes in actualized terms, beyond conceptual and normative commitments to ethics. It is best presented towards the end of a module, after the traditional approach to CSR is sufficiently covered, as it introduces a political and practical dimension that is often left out of the CSR literature. In introducing the case, the instructor should start by discussing how political risk in emerging markets, particularly in Africa, may be very different from those in other regions. The instructor may also show that Africa provides sufficient returns on investment in certain industries, in spite of the political risk involved. Thus, this case study should be framed in a way to help students consider issues of political risk in tandem with issues of CSR.

The learning outcomes for this case are associated primarily with critical thinking and analytical skills. First, students should understand why companies choose to invest in markets that present significant political risk. Second, students should understand how companies can strategically manage political risk as a part of their CSR and communication initiatives. Third, students should assess whether CSR carries universal ethical connotations, or whether CSR should look different in different political and cultural contexts. More specifically, students should identify a distinction between broad conceptions of CSR and specific, locally negotiated implementations that are more inclusive of the actual concerns of local community stakeholders.

\section{REFERENCES}

Africa Juice. (n.d.). Retrieved from www.africajuice.com

Aglionby, J., \& Honan, E. (2016, October). Ethiopian protesters ramp up attacks on foreign companies.

Financial Times. Retrieved from www.ft.com/content/a1ceca0e-8b11-11e6-8cb7-e7ada1d123b1

Bertelsmann Stiftung. (2016). BTI 2016 - Ethiopia Country Report. Gütersloh. Retrieved from https://www.btiproject.org/fileadmin/files/BTI/Downloads/Reports/2016/pdf/BTI_2016_Ethiopia. pdf

Button, K. (2020). The economics of Africa's floriculture air-cargo supply chain. Journal of Transport Geography, 86. https://doi.org/10.1016/j.jtrangeo.2020.102789

Dahir, A.L. (2016, September). Ethiopia's political protests are escalating with a fire at a major prison. Quartz. Retrieved from www.qz.com/774581/ethiopias-political-protests-are-escalating-with-afire-at-a-major-prison

Driessen, M. (2020). Email Interview with Author.

Ethiopia: Country Risk Summary. (2009, July). Economic Intelligence Unit ViewsWire.

Ethiopia: Country Risk Summary. (2012, February). Economic Intelligence Unit ViewsWire.

Ethiopia: Country Risk Summary. (2013, September). Economic Intelligence Unit ViewsWire.

Ethiopian Investment Commission. (2009). Africa Juice. Retrieved from www.investethiopia.gov.et/stories/success-stories/216-africa-juice

FAO. (2020, February). Major Tropical Fruits Market Review. Food and Agriculture Organization of the United Nations. Retrieved from http://www.fao.org/3/ca9213en/ca9213en.pdf

Ger, G. (1997). Human Development and Humane Consumption: Well-Being beyond the 'Good Life.' Journal of Public Policy \& Marketing, 16(1), 110-125.

GRO Intel. (2015, March). East African Floriculture Blossoming. Retrieved from https:/grointelligence.com/insights/articles/east-african-floriculture-blossoming

Kline, J. (2010). Ethics for International Business: Decision-Making in a Global Political Economy. NY: Routledge.

Livingstone, G. (2013). America's Backyard: The United States and Latin America from the Monroe Doctrine to the War on Terror. London: Zed Books.

Nazret. (2011, April). Tropical Fruit Juice Project Helping to Spur Economic Revival in Ethiopia. Retrieved from www.nazret.com/blog/index.php/2011/05/12/tropical-fruit-juice-project-helpingto-spur-economic-revival-in-ethiopia 
Price, E. (2013, October). FC, GAFSP Invest \$6 million to Fund Expansion of Ethiopia-Based africaJUICE. International Finance Corporation. Retrieved from www.ifcext.ifc.org/ifcext/pressroom/IFCPressRoom.nsf/0/40B8F2DDAA955ECA85257C12005 $2425 \mathrm{~F}$

Schemm, P. (2016, November). Investors shy away from Ethiopia in the wake of violent protests. Washington Post. Retrieved from https:/www.washingtonpost.com/world/africa/investors-shyaway-from-ethiopia-in-the-wake-of-violent-protests/2016/11/01/2d998788-9cae-11e6-b552b1f85e484086 story.html

Secorun, L. (2016, October). Ethiopia vows to protect European companies after farms attacked. The Guardian. Retrieved from www.theguardian.com/sustainable-business/2016/oct/26/ethiopiavows-to-protect-european-companies-after-farms-attacked

Stratfor Worldview. (2017, March). Ethiopia: Can the Landlocked Power Restore Its Former Glory? Retrieved from www.stratfor.com/analysis/ethiopia-can-landlocked-power-restore-its-formerglory

Tropical Fruits. (2009). Food and Agriculture Organization of the United Nations. Food Outlook - Global Market Analysis. Retrieved from http://www.fao.org/3/ak341e/ak341e13.htm\#aaa

Tropical Fruits. (2018). OEC - Observatory of Economic Complexity. Retrieved from https://oec.world/en/profile/hs92/tropicalfruits?redirect=true\#: :text=In\%202018\%2C\%20Tropical\%20Fruits\%20were, $0.072 \% 25 \% 20$ of $\%$ 20total\%20world \%20trade

Workman, D. (2020, May). Flower Bouquet Exports by Country. World's Top Exports. Retrieved from http://www.worldstopexports.com/flower-bouquet-exports-country 